\title{
ANALISIS GAYA BELAJAR DAN POLA ASUH ORANG TUA DALAM MERAIH PRESTASI BELAJAR SISWA KELAS VB SD NEGERI 4 KUTOSARI TAHUN AJARAN 2020/2021
}

\author{
Lin Wahyuni ${ }^{1}$, Suhartono ${ }^{2}$, Kartika Chrysti Suryandari ${ }^{3}$ \\ Universitas Sebelas Maret \\ linwahyuni177@gmail.com
}

\section{Article History}

accepted 30/8/2021

\begin{abstract}
Analysis of Learning Styles and Parenting Patterns of Parents in Achieving Learning Achievement for Class VB Students at Elementary School 4 Kutosari. This study aims to analyze trends in student learning styles and types of parenting styles in achieving learning achievement for class VB at Elementary School 4 Kutosari. The method of data analysis was carried out by qualitative descriptive analysis. Data collection was carried out using questionnaires, interviews and documentation studies. The population in this study were students of class VB Elementary School 4 Kutosari amount 26 students with details of 10 female students and 16 male students The results showed that the learning achievement in class VB was good. In achieving learning achievement, the tendency of students' learning styles are auditory, totaling ten students, five students with kinesthetic learning style and five students with visual learning style. The indicators of each learning style have been seen in each student with their learning style. The parenting type of class VB students dominantly applies democratic parenting. As many as 21 parents used democratic parenting, the rest used authoritarian parenting. Students with high learning achievement have parents with democratic parenting patterns. Students with low learning achievement have parents with authoritarian parenting. The indicators of each democratic parenting and authoritarian parenting pattern have been fulfilled.

Keywords: learning style, parenting style, learning achievment
\end{abstract}

\begin{abstract}
Abstrak
Analisis Gaya Belajar dan Pola Asuh Orang Tua dalam Meraih Prestasi Belajar Siswa Kelas VB SD Negeri 4 Kutosari Tahun Ajaran 2020/2021. Penelitian ini bertujuan untuk mengalisis kecenderungan gaya belajar siswa dan tipe pola asuh orang tua dalam meraih prestasi belajar kelas VB SD Negeri 4 Kutosari Tahun Ajaran 2020/2021. Metode analisis data dilakukan dengan analisis deskriptif kualitatif. Pengambilan data dilakukan dengan menggunakan teknik angket, wawancara dan studi dokumentasi. Populasi dalam penelitian ini adalah siswa kelas VB SD Negeri 4 Kutosari yang berjumlah 26 siswa dengan perincian sepuluh siswa perempuan dan 16 siswa laki-laki. Hasil penelitian menunjukkan prestasi belajar di kelas VB baik. Kecenderungan gaya belajar peserta didik yaitu auditori yang berjumlah sepuluh siswa, lima siswa bergaya belajar kinestetik dan lima siswa bergaya belajar visual. Indikator dari masingmasing gaya belajar sudah terpenuhi pada masing-masing siswa dengan gaya belajarnya. Tipe pengasuhan orang tua siswa kelas VB dominan menerapkan pola asuh demokratis. Sebanyak 21 orang tua membiasakan pola asuh demokratis, sisanya membiasakan pengasuhan otoriter. Siswa dengan prestasi belajar tinggi mempunyai orang tua dengan pola pengasuhan demokratis. Siswa dengan prestasi belajar rendah mempunyai orang tua dengan pola asuh otoriter. Indikator dari masing-masing pola asuh demokratis dan pola asuh otoriter sudah terpenuhi.
\end{abstract}

Kata Kunci: gaya belajar, pola asuh orang tua, prestasi belajar 


\section{PENDAHULUAN}

Prestasi belajar siswa dipengaruhi oleh tiga faktor, yaitu faktor internal, faktor eksternal dan faktor pendekatan belajar (Syah, 2014). Faktor internal yang memengaruhi prestasi belajar seorang peserta didik adalah gaya atau cara belajar salah satunya. Gaya belajar menurut Dodge dan kawan-kawan (Hildayani, 2010) diklasifikasikan menjadi tiga macam yaitu gaya belajar auditori, gaya belajar visual dan gaya belajar kinestik. Gaya belajar visual adalah gaya belajar dengan cara melihat, mengamati, memandang dan mengandalkan indra penglihatan (mata) selama proses pembelajaran berlangsung. Gaya belajar visual memiliki indikator: (a) belajar dengan cara visual; (b) suka membaca; (c) rapi dan teratur; (d) sulit menerima informasi verbal (DePorter dan Hernacki, 2015).

Siswa dengan gaya belajar auditori pada umumnya memaksimalkan penggunaan indra pendengar (telinga) dalam proses penyerapan informasi dan hasil belajarnya paling baik apabila pembelajaran diberikan dengan cara mendengarkan bunyi atau kata-kata auditori (DePorter dan Hernacki, 2015). Indikator gaya belajar auditori yaitu: (a) belajar dengan cara mendengarkan; (b) baik dalam aktivitas lisan; (c) mudah terganggu dengan keributan; (d) lemah dalam aktivitas visual. siswa dengan tipe gaya belajar kinestetik memperoleh informasi dengan mengutamakan indera perasa dan gerakan-gerakan fisik (DePorter dan Hernacki, 2015). Siswa dengan gaya belajar kinestetik adalah siswa yang mudah menangkap informasi apabila ia bergerak, meraba, atau mengambil tindakan dengan praktik atau pengalaman belajar secara langsung. Indikator gaya belajar kinestetik yaitu: (a) belajar dengan aktivitas fisik; (b) berorientasi pada fisik dan banyak bergerak; (d) menghafal dengan cara bergerak; (e) lemah terhadap aktivitas verbal (DePorter dan Hernacki, 2015).

Gaya belajar bersifat individual bagi masing-masing siswa dan mampu menjadi pembeda antar siswa. Semakin sesuai gaya belajar dengan kepribadian siswa, maka akan semakin tinggi prestasi siswa tersebut (Khoeron, dkk., 2014). Selain faktor gaya belajar, faktor lain yang dapat mempengaruhi prestasi belajar adalah pola asuh orang tua yang diterapkan dalam keseharian.

Pola asuh orang tua adalah salah satu faktor yang memengaruhi prestasi siswa karena orang tua berperan penting dalam membiasakan cara belajar pada anak, anak akan mengikuti cara belajar yang diajarkan oleh orang tuanya dan akan berdampak pada prestasi belajar anak (Chayati, 2014). Cara orang tua dalam mendidik anaknya tentu berbeda-beda, ada yang menggunakan pola asuh sangat menutut, ada juga yang menggunakan pola asuh penyabar dan ada pula yang tidak pernah menutut sama sekali. Diana Baumrind pada tahun 1927 (Desmita, 2012) mengklasifikasikan tiga tipe pola pengasuhan, yaitu otoriter, otoritatif dan permisif.

Pola asuh otoriter merupakan pola asuh yang mengutamakan membantuk kepribadian anak dengan menetapkan standar yang harus dituruti dan disertai dengan ancaman. Indikator pola asuh otoriter yaitu: (a) orang tua menerapkan peraturan yang ketat; (b) orang tua jrang memberikan hadiah atau pujian; (c) berorientasi pada hukuman fisik; (d) semua aturan yang dibuat harus dipatuhi anak; (e) tidak adanya kesempatan untuk mengemukakan pendapat (Latipah, 2012).

Pola asuh demokratis merupakan pola asuh yang mana orang tua mendorong anak untuk mandiri, tetapi tetap memberikan batasan-batasan serta mengontrol perilaku anak. Orang tua memberikan ruang kepada anak untuk membicarakan apa yang mereka inginkan atau harapan dari kedua orang tuanya (Septiari, 2012). Indikator pola asuh demokratis menurut Triodhonanto (2014) yaitu (a) orang tua bersikap hangat dan suportif; (b) memberikan kesempatan anak untuk berpendapat; (c) orang tua memberikan kontrol yang baik atas tindakan anak; (d) orang tua mendorong anak bersikap mandiri; (e) orang tua menunjukkan kepeduliannya kepada anak. 
Pola asuh permisif didefinisikan sebagai pola asuh yang membebaskan anak untuk melakukan apa saja yang ingin dilakukan tanpa mempertanyakannya (Adawiah, 2017). Menurut Latipah (2012) indikator dari pola asuh ini sebagai berikut: (a) orang tua membiarkan anak melakukan apa yang mereka inginkan; (b) orang tua terlalu fokus pada keinginan anak; (c) anak tidak dihukum meskipun melanggar aturan; (d) orang tua memberikan kebebasan tanpa ada batasan. Faktor gaya belajar (learnig style) dan pola asuh (parenting style) yang beragam dalam meraih prestasi belajar peserta didik, jika dianalisis dimungkinkan dapat menjadi sarana untuk meningkatkan motivasi siswa dalam belajar yang nantinya akan mendorong peningkatan prestasi belajar siswa. Penelitian ini bertujuan untuk mengalisis kecenderungan gaya belajar siswa dan tipe pola asuh orang tua dalam meraih prestasi belajar kelas VB SD Negeri 4 Kutosari Tahun Ajaran 2020/2021.

\section{METODE}

Pendekatan penelitian ini adalah pendekatan kualitatif dan jenis penelitian bersifat deskriptif. Subjek dalam penelitian ini adalah 1 orang guru kelas VB, siswa kelas VB berjumlah 26 yang terdiri atas 10 siswa perempuan dan 16 siswa laki-laki, dan orang tua dari siswa kelas VB SD Negeri 4 Kutosari Tahun Ajaran 2020/2021. Penlitian ini dilaksanakan di SD Negeri 4 Kutosari Tahun Ajaran 2020/2021. Pengumpulan data dengan teknik angket terbuka, wawancara dan studi dokumen. Teknik analisis data menggunakan teknik triangulasi, dimana dalam teknik ini pengumpulan data bersifat penggabungan dari berbagai teknik dan menggunakan tiga langkah pengolahan data, yakni reduksi, menyajikan data, dan mengambil kesimpulan (Sugiyono, 2015). Selain itu, data kualitatif yang lain dalam penelitian ini diperoleh dari wawancara siswa, guru dan orang tua yang digunakan untuk mempertegas jawaban kemudian dideskripsikan dalam pembahasan.

\section{HASIL DAN PEMBAHASAN}

Pengamatan awal terhadap siswa dilaksanakan selama proses pembelajaran berlangsung. Berdasarkan hasil penelitian yang telah dilaksanakan pada siswa, guru dan orang tua kelas VB SD Negeri 4 Kutosari tahun ajaran 2020/2021 diperoleh bahwa: (1) dalam meraih prestasi belajar kecenderungan gaya belajar siswa yaitu auditori dengan jumlah 16 siswa dan kecenderungan tipe gaya belajar visual serta kinestetik masing-masing lima siswa; (2) pola asuh yang dibiasakan orang tua siswa kelas VB yaitu sebanyak 21 orang tua bertipe pengasuhan demokratis serta lima orang tua menerapkan pola pengasuhan otoriter

Dalam proses meraih prestasi belajar, siswa kelas VB SD Negeri 4 Kutosari Tahun Ajaran 2020/2021 mempunyai gaya belajar yang berbeda-beda. Berdasarkan penelitian Untuk tipe gaya belajar terbanyak yaitu gaya belajar auditori sebanyak 16 siswa dari total keseluruhan 26 siswa, sedangkan gaya belajar visual dan kinestetik masing masing sebanyak lima siswa dari total peserta didik sebanyak 26 orang. Berdasarkan penelitian dengan teknik analisis pada dokumen rapor semester ganjil siswa kelas VB SD Negeri 4 Kutosari Tahun Ajaran 2020/2021 prestasi belajar di siswa kelas VB sangat baik. Hal tersebut didukung dengan teknik wawancara dengan orang tua dan guru kelas.

\begin{tabular}{|c|c|c|c|}
\hline No & Aspek & Pola Pertanyaan & Hasil Temuan \\
\hline 1 & Kognitif & $\begin{array}{l}\text { Kemampuan } \\
\text { siswa kelas VB. }\end{array}$ & $\begin{array}{l}\text { Kemampuan kognitif } \\
\text { siswa kelas VB baik. }\end{array}$ \\
\hline 2 & Afektif & $\begin{array}{l}\text { Kemampuan afektif siswa } \\
\text { kelas VB }\end{array}$ & $\begin{array}{l}\text { Kemampuan afektif } \\
\text { siswa kelas VB baik. }\end{array}$ \\
\hline 3 & Psikc & $\begin{array}{l}\text { Kemampuan psikomotor } \\
\text { siswa kelas VB. }\end{array}$ & $\begin{array}{l}\text { Kemampuan psikomotor } \\
\text { siswa kelas VB baik. }\end{array}$ \\
\hline
\end{tabular}

Tabel 4.1 data transkrip wawancara prestasi belajar 
Berdasarkan penelitian, siswa dengan prestasi belajar tinggi membiasakan gaya belajar auditori, siswa dengan prestasi belajar rendah membiasakan gaya belajar visual, dan siswa dengan prestasi belajar yang rendah membiasakan gaya belajar kinestetik. Berdasarkan hasil analisis angket, yang didukung dengan teknik wawancara siswa dengan gaya belajar auditori menunjukkan bahwa semua indikator gaya belajar ini terpenuhi. Indikator gaya belajar auditori yaitu : (1) Belajar dengan cara mendengarkan; (2) Baik dalam aktivitas lisan; (3) Mudah terganggu dengan keributan; dan (4) Lemah dalam aktivitas visual. Siswa yang membiasakan gaya belajar auditori berjumlah 16 siswa. Data tersebut juga didukung oleh teknik wawancara yang dilakukan oleh peneliti terhadap informan.

Berdasarkan hasil analisis angket, yang didukung dengan teknik wawancara siswa dengan gaya belajar visual menunjukkan bahwa semua indikator gaya belajar ini terpenuhi. Indikator gaya belajar visual yaitu: (1) Rapi dan teratur; (2) Belajar dengan cara melihat; (3) Suka membaca; dan (4) Sulit menerima instruksi verbal. Siswa yang membiasakan gaya belajar visual berjumlah lima siswa. Data tersebut juga dierkuat dengan teknik wawancara yang dilakukan oleh peneliti kepada informan.

Berdasarkan hasil analisis angket, yang didukung dengan teknik wawancara siswa dengan gaya belajar kinestetik menunjukkan bahwa semua indikator gaya belajar ini terpenuhi. Indikator gaya belajar kinestetik yaitu: (1) belajar dengan aktivitas fisik; (2) berorientasi pada fisik dan banyak bergerak; (3) lemah dalam aktivitas; dan (4) menghafal dengan cara bergerak. siswa dengan dominan tipe gaya belajar kinestetik berjumlah lima anak. Data tersebut juga dierkuat dengan teknik wawancara yang dilakukan oleh peneliti kepada informan.

Berdasarkan analisis hasil angket, sejumlah 21 siswa mempunyai orang tua berpola asuh demokratis dan lima siswa di kelas VB SD Negeri 4 Kutosari Tahun Ajaran 2020/2021 mempunyai orang tua dengan tipe pengasuhan otoritatif.. Tidak ada orang tua di kelas VB yang menerapkan pola asuh permisif dalam kesehariannya. Berdasarkan penelitian, siswa dengan prestasi belajar tinggi di kelas VB mendapati orang tuanya bertipe pengasuhan demokratis, siswa dengan prestasi belajar sedang mempunyai orang tua dengan tipe pengasuhan demokratis, dan siswa dengan prestasi belajar yang rendah mempunyai orang tua dengan pola asuh otoriter.

Berdasarkan hasil analisis angket, yang didukung dengan wawancara siswa dengan pola pengasuhan otoriter menunjukkan bahwa semua indikator pengasuhan ini terpenuhi. Indikator dari pola asuh otoriter yaitu: (1) penerapan aturan yang ketat; (2) orang tua jarang memberikan hadiah; (3) berorientasi pada hukuman; (4) semua aturan harus ditaati oleh anak; (5) tidak adanya kesempatan bagi anak untuk berpendapat. Dominan orang tua yang membiasakan pola asuh otoriter berjumlah lima. Data tersebut juga didukung oleh teknik wawancara yang dilakukan oleh peneliti dengan informan.

Berdasarkan hasil analisis instrumen angket, yang didukung dengan wawancara siswa dengan pola pengasuhan demokratis menunjukkan bahwa semua indikator pengasuhan ini terpenuhi. Indikator pola asuh demokratis yaitu: (1) orang tua bersikap hangat dan suportif; (2) memberikan kesempatan bagi anak untuk berpendapat; (3) orang tua masih tetap memberikan kontrol yang baik atas tindakan anak; (4) orang tua mendorong anak untuk bersikap mandiri; (5) orang tua menunjukkan keedulian tehadap anak. dominan orang tua yang membiasakan tipe pengasuhan demokratis adalah 21 orang tua.

Tiga aspek yang merujuk pada pencapaian prestasi belajar yaitu aspek kognitif, aspek psikomotor dan aspek afektif. Secara keseluruhan siswa kelas VB SD Negeri 4 Kutosari Tahun Ajaran 2020/2021 sudah mempunyai prestasi belajar yang membanggakan. Pada aspek kognitif, siswa mampu meraih nilai yang baik terutama saat ujian atau ulangan pada semua mata pelajaran. Hampir semua siswa di kelas tersebut mendapatkan nilai ujian di atas kriteria ketuntasan minimal. Aspek psikomotor 
dari siswa kelas VB secara umum baik. Penguasaan keterampilan siswa dalam tiaptiap mata pelajaran sudah baik. Pada aspek afektif siswa kelas VB SD Negeri 4 Kutosari baik.

Dalam meraih prestasi belajarnya, salah satu faktor yang berpengaruh adalah gaya belajar. Sejumlah 16 siswa kelas VB SD Negeri 4 Kutosari dalam meraih prestasi belajarnya menerapkan gaya belajar auditori. Semua indikator terlihat pada siswa dengan gaya belajar tersebut. Sepuluh siswa menerapkan gaya belajar visual dan gaya belajar kinestetik yang terdiri atas lima siswa bertipe visual dan lima siswa lainnya bertipe kinestetik. Seluruh indikator pada masing-masing gaya belajar sudah terlihat pada siswa kelas VB. Berdasarkan hasil wawancara dan studi dokumen serta pengisian angket bahwa diantara gaya belajar visual, gaya belajar auditori dan gaya belajar kinestetik semua gaya belajar adalah baik dalam meraih prestasi belajar. Masing-masing gaya belajar mempunyai karakteristik yang membedakan antara satu dengan yang lainnya. Gaya belajar yang terbaik dalam meraih prestasi belajar kembali kepada individu masing-masing siswa. Hanya gaya belajar yang cocok dengan dirinya yang dapat membantu mempermudah dalam menyerap dan memahami suatu informasi tertentu (Khoeron, dkk., 2014).

Faktor lain yang mempengaruhi prestasi belajar siswa adalah pola asuh orang tua. Pola asuh yang diterapkan orang tua di kelas VB beragam. Sebanyak 21 orang tua menerapkan pola asuh demokratis dalam kesehariannya. Semua indikator dari pola asuh demokratis terpenuhi pada orang tua dengan tipe pengasuhan tersebut. Selebihnya orang tua dari siswa kelas VB mempergunakan tipe pola asuh otoriter. Seluruh indikator pada pola asuh tersebut terlihat pada orang tua dengan tipe pengasuhan otoriter. Berdasarkan penelitian melalui teknik wawancara dan studi dokumen serta pengisian angket pola asuh yang baik dalam meraih prestasi belajar adalah pola asuh demokratis. Dari hasil yang ditemui di lapangan, dapat diketahui bahwa anak dari orang tua yang menerapkan pola asuh otoriter mempunyai prestasi belajar yang rendah. Dalam mengasuh anaknya, orang tua menerapkan dengan keras, disiplin dan tidak segan memberikan hukuman untuk anak ketika anak melakukan kesalahan. Hal tersebut sejalan dengan opini Wibowo dan Gunawan (2015) bahwa pola suh otoriter merupakan pola pengasuhan dengan karakter orang tua yang keras dan cenderung memaksakan kehendak tanpa menanyakan pendapat anak.

\section{SIMPULAN}

Berdasarkan hasil penelitian maka dapat disimpulkan bahwa dalam meraih presasi belajar yang baik di kelas VB SD Negeri 4 Kutosari Tahun Ajaran 2020/2021 gaya belajar yang diterapkan 26 siswa kelas yaitu 16 siswa berkecenderungan gaya belajar auditori, lima siswa berkecenderungan gaya belajar visual dan lima siswa dengan kecenderungan gaya belajar kinestetik. Semua indikator dari masing-masing gaya belajar sudah terpenuhi. Tipe pengasuhan yang dibiasakan oleh orang tua dalam meraih prestasi belajar yang baik dari 26 siswa kelas VB SD Negeri 4 Kutosari Tahun Ajaran 2020/2021 yaitu 16 orang tua menerapkan pola asuh demokratis dan sepuluh orang tua siswa menggunakan tipe pengasuhan otoriter. Indikator dari masing-masing pola asuh demokratis dan pola asuh otoriter sudah terpenuhi. 


\section{DAFTAR PUSTAKA}

Adawiah, R. (2017). Pola Asuh Orang Tua dan Implikasinya terhadap Pendidikan Anak (Studi pada Masyarakat Dayak di Kecamatan Halong Kabupaten Balangan). Jurnal Pendidikan, 7 (1), 33-48. Diperoleh pada 9 Desember 2020 dari https://media.neliti.com/media/publications/121261-ID-pola-asuh-orang-tua-danimplikasinya-ter.pdf

Chayati, N. N., (2014). Pengaruh Pola Asuh Orangtua dan Motivasi Belajar terhadap Prestasi Siswa di Sekolah Dasar Islam Terpadu (SDIT) Nidaul Hikmah Salatiga Tahun Ajaran 2013/2014. Skripsi Tidak Dipublikasikan. Sekolah Tinggi Agama Islam Negeri Salatiga, Salatiga.

DePorter B. \& Hernacki M. (2015). Quantum Learning, Membiasakan Belajar Nyaman dan Menyenangkan. Bandung: PT Mizan Pustaka

Desmita. (2012). Psikologi Perkembangan A. Bandung: Rosdakarya

Gunarsa, D. S. (2009). Psikologi Praktis Anak, Remaja dan Keluarga. Jakarta: Gunung Mulia.

Hildayani, R. (2010). Psikologi Perkembangan Anak. Jakarta: Penerbit Universitas Terbuka

Khoeron, I. R., Sumarna, N., \& Permana, T. (2014). Pengaruh Gaya Belajar Terhadap Prestasi Belajar Peserta Didik Pada Mata Pelajaran Produktif. Journal of Mechanical Engineering Education, 1 (2), 291-297. Diperoleh pada 9 Desember 2020 dari https://ejournal.upi.edu

Latipah, E. (2012). Pengantar Psikologi Pendidikan. Yogyakarta: Pedagogia

Riduwan. (2012). Belajar Mudah Penelitian Untuk Guru, Karyawan, Peneliti, Pemula. Bandung: Alfabeta

Septiari, B. B. (2012). Mencetak Balita Cerdas dan Pola Asuh Orang Tua. Yogyakarta: Nuha Medika

Sugiyono. (2015). Metode Penelitian Pendidikan Pendekatan Kuantitatif, Kualitatif, dan $R \& D$. Bandung: Penerbit Alfabeta.

Syah, M. (2014). Psikologi Pendidikan dengan Pendekatan Baru. Bandung: Remaja Rosdakarya.

Triodhonanto, A. (2014). Mengembangkan Pola Asuh Demokratis. Jakarta: Gramedia. 